\title{
Sertanejo biodigestor: a social technology, an alternative source of energy
}

Biodigestor sertanejo: uma tecnologia social, fonte alternativa de energia

Reginaldo Alves de Souza ${ }^{1}$ (D) Marília Regina Costa Castro Lyra ${ }^{1}$ (), Renata Maria Caminha Mendes de Oliveira Carvalho ${ }^{1}$ (), José Coelho de Araújo Filho ${ }^{1}$ (1)

\section{ABSTRACT}

The use of biogas as an alternative to using liquefied petroleum gas (LPG) for cooking food in the context of family farming is something recent and has ample room for growth. The aim of this study was to evaluate the use of the Sertanejo biodigester by farming families as a social technology for cooking gas production, as well as an alternative energy source. It also aimed to identify elements which contribute to disseminating this technology as an alternative to the use of firewood, charcoal and LPG. Quali-quantitative approaches were used following the exploratory method, with interviews and non-probabilistic sampling. A population with 132 units of biodigesters in the Agreste mesoregion of the State of Pernambuco was considered, with 83 interviews being collected. The results indicated that the Sertanejo biodigester social technology provides an increase in the income of farming families, avoids the use of firewood and charcoal for cooking food and produces biofertilizer for crops. They also showed that its non-continuous use or deactivation is related to a lack of raw material and the need for maintenance. Given this scenario, its implementation must consider the availability of a raw material source in the production unit and the potential for biogas production from the existing herd and consumption demand. It is recommended to strengthen arguments of economic and environmental impact for low-income families to disseminate this technology; to encourage the use of biogas associated with other activities in the production system; and to incorporate biodigestor social technology in rural credit financing lines.

Keywords: Family farming; social technology; biogas; National Rural Housing Program; climate changes; semi-arid region.

\section{RE S U M 0}

A utilização do biogás como alternativa ao uso do gás liquefeito de petróleo (GLP) para cocção de alimentos no âmbito da agricultura familiar é algo recente e com amplo espaço de crescimento. $O$ objetivo deste estudo foi avaliar o uso do biodigestor sertanejo por agricultores familiares como tecnologia social para produção de gás de cozinha, como fonte alternativa de energia. Visou, também, identificar elementos que contribuam para a divulgação e a disseminação dessa tecnologia como alternativa ao uso de lenha, carvão vegetal e GLP. Utilizou-se abordagens quali-quantitativas, seguindo o método exploratório, com entrevistas e amostragem não-probabilística. Foi considerada uma população com 132 unidades de biodigestores na mesorregião do Agreste Pernambucano, sendo coletadas 83 entrevistas. Os resultados indicaram que a tecnologia social do biodigestor sertanejo proporciona incremento na renda das famílias agricultoras, evita o uso de lenha e carvão vegetal para cocção de alimentos e produz biofertilizante para os cultivos. Também mostraram que o seu uso não contínuo ou desativação está relacionado à falta de matéria-prima e à necessidade de manutenção. Diante desse cenário, sua implantação deve considerar a disponibilidade de fonte de matéria prima na unidade de produção e o potencial de produção de biogás a partir do rebanho existente e da demanda de consumo. Recomenda-se fortalecer os argumentos de impacto econômico e ambiental para as famílias de baixa renda para a disseminação dessa tecnologia; estimular o uso do biogás associado às demais atividades do sistema de produção e incorporar a tecnologia social biodigestor nas linhas de financiamento de crédito rural.

Palavras-chave: agricultura familiar, tecnologia social; biogás; Programa Nacional de Habitação Rural; mudanças climáticas; semiárido.

\footnotetext{
${ }^{1}$ Instituto Federal de Educação, Ciência e Tecnologia de Pernambuco - Recife (PE), Brazil.

Correspondence address: Reginaldo Alves de Souza - Rua Visconde de Mamanguape, 40 - Encruzilhada - CEP: 52030-010 - Recife (PE), Brazil. E-mail: alves.reginaldo@gmail.com
}

Conflicts of interest: the authors declare that there are no conflicts of interest.

Funding: Conselho Nacional de Desenvolvimento Científico e Tecnológico (CNPq).

Received on: 11/23/2020. Accepted on: 08/05/2021.

https://doi.org/10.5327/Z21769478987

This is an open access article distributed under the terms of the Creative Commons license. 


\section{Introduction}

The causes and consequences of climate change demand efforts in different sectors and different players. One of these efforts concerns the search for alternatives to the current hegemonic energy matrix. Another refers to the adaptation to ongoing climate processes. In this universe of technological options, the biodigester is considered a social technology for the production of biogas (methane) to supply part of the energy needs of family farming as an alternative to the use of Liquefied Petroleum Gas (LPG), firewood and charcoal.

According to Martins et al. (2010), the ability of family farmers to adapt to climate change cannot be reduced to the possibility of adopting some practices apparently adjusted to a certain abnormal climate phenomenon, but it has to be understood as a result of the learning capacity to deal with the new situation.

Discussions around biogas production are not limited to a technical debate about the fermentation process and the efficiency of biodigester models. It is also associated with the broader debate on environmental sustainability, the growing need for clean energy production, reduced use of natural resources and especially related to a reduction in greenhouse gas (GHG) emissions. In the opinion of specialists regarding this theme, it is important to consider that global warming caused by the increase in the emission of greenhouse gases in the Earth's atmosphere can cause changes to terrestrial ecosystems, modifying global vegetation patterns (Nobre et al., 2007, p. 7). Such threats were recently reaffirmed in the sixth Assessment Report of the Intergovernmental Panel on Climate Change, which reveals that the global surface temperature will continue to increase until at least the middle of the century in all considered emission scenarios (IPCC, 2021, p. 18).

Under this perspective, there is a growing need to move towards expanding the use of renewable, non-polluting or low-emission greenhouse gas sources of energy to the detriment of non-renewable energy, the main GHG emitters. Data presented by the Energy Research Company (EPE) (Table 1) indicate that the participation of renewable sources in the national energy matrix in the period from 2008 to 2018 did not change significantly, varying negatively when evaluating the share of renewable sources, which contributed $45.6 \%$ to the national energy matrix in 2008, and represent $45.3 \%$ in 2018 (EPE, 2019, p. 56).

However, it can be seen that there are changes to the shares in the scope of renewable sources, with a reduction of 1.5 percentage points (pp) in the use of hydraulic energy, 3.2 pp in the use of firewood and charcoal, and an increase in the share of other renewables of $2.5 \mathrm{pp}$; furthermore, the contribution of solar energy begins in 2018 with $0.1 \%$ of the national energy matrix. Despite the diversification of the national energy matrix, biogas is still not highlighted as a renewable source of large-scale energy potential, being considered by EPE as incipient (EPE, 2019, p. 55-56).

Interest in this research was aroused by the potential that the biodigester has for producing cooking gas associated with a considerable number of farming families that can incorporate this technology into their production processes, and takes the project "Biodigesters, A Social Technology in the National Rural Housing Program (PNHR)", implemented by the NGO Diaconia in 2013, as a reference, with the purpose of disseminating the use of biodigesters through training, to produce and manage cooking gas (methane biogas).

One of the main references in the social technologies (ST) registry with a focus on rural development and sustainability is the Bank of Social Technologies (BTS) of Fundação Banco do Brasil (FBB), where the backcountry biodigester is described as a social technology that produces biogas from animal manure, and is used in stoves to prepare family food (FBB, 2018).

Several authors point out that the emergence of ST is due to an earlier process associated with appropriate technologies. Rodrigues and Barbieri (2008, p. 1071) describe the emergence of this movement in the 1960s and 1970s, according to which - and citing Kaplinski (1990 apud Rodrigues and Barbieri, 2008, p. 1071) -, "it would be associated with a reaction to post-war economic growth patterns." In addition to the term ST, the authors retrieved other terms related to the example of the term intermediate technology created by Schumacher (1979 apud Rodrigues and Barbieri, 2008, p. 1071), according to the authors, indicating "a technology that combines elements of traditional technologies with those of advanced technologies." The authors also refer to the terms alternative technology, defended by Dickson (1974 apud Rodrigues and Barbieri, 2008, p. 1071), and soft technology, proposed by Clarke (1976 apud Rodrigues and Barbieri, 2008, p. 1071).

Table 1 - Share of different energy sources in the national energy matrix, from 2008 to 2018 .

\begin{tabular}{|l|c|c|}
\hline \multirow{2}{*}{ Energy sources } & \multicolumn{2}{|c|}{ Share (\%) } \\
\cline { 2 - 3 } Non-renewable & 2008 & 2018 \\
\hline Oil and Derivatives & 54.5 & 54.7 \\
\hline Natural gas & 36.7 & 34.4 \\
\hline Mineral Coal and Coke & 10.3 & 12.5 \\
\hline Uranium (U⿻ $\mathrm{O}_{8}$ ) & 5.5 & 5.8 \\
\hline Other non-renewables & 1.5 & 1.4 \\
\hline Renewables & 0.5 & 0.6 \\
\hline Biomass (derived from sugarcane) & 17.0 & 45.2 \\
\hline Hydraulics & 14.1 & 17.4 \\
\hline Firewood and charcoal & 11.6 & 12.6 \\
\hline Other renewables & 2.8 & 8.4 \\
\hline Wind & - & 5.3 \\
\hline Solar & - & 1.4 \\
\hline
\end{tabular}

Source: adapted from EPE (2019). 
In this historical review of the emergence of ST, Dagnino et al. (2004, p. 19) refer to the struggle of the Indian people against the British rule, where the reformers of that society had "the rehabilitation and development of traditional technologies practiced in their villages" as a fighting strategy, having as a great reference the spinning wheel machine popularized by Gandhi, recognized as the first technologically appropriate equipment. However, according to the authors, the concept of appropriate technology (AT) was introduced in the Western world as a result of the creation by Schumacher of the Appropriate Technology Development Group and the publication of the book Small in 1973 is beautiful: economics as if people mattered, translated into over 15 languages. For the authors, this movement towards appropriate technology lost momentum in the early 1980s as the neoliberal thought expanded.

Ventura et al. (2012, p. 606) suggest the need to discuss incorporating social technologies to the new institutional framework of the Post-Kyoto climate regime as one of the instruments to combat climate change, in fact contributing to negotiate GHG emission reduction projects in the carbon market, as they not only promote the transfer of technologies, but also the development of technologies suited to each social and environmental reality of the host communities. According to the authors, applying technologies for coexistence with the semi-arid region, especially the biodigester, cisterns and desalination plant, has been characterized as a cultural perspective that guides development with the purpose of improving living conditions and promoting citizenship through socioeconomic and technological initiatives.

In addition, Jiménez and Zambrano (2018) conclude that social technologies present themselves as modern options and adapt to small and medium rural enterprises with a satisfactory cost-benefit ratio that enables the relief of structural problems, thereby allowing the direct participation of rural communities in the implementation process and effectively contributing to develop individual and collective awareness of sustainability in the semi-arid region of the country.

According to Gualdani and Burgos (2020), the concept of ST is quite broad and flexible thanks to its experimentation character and the scope of possibilities for framing different types of solutions to local problems, with ST being defined by several authors as techniques, procedures, processes and methodologies collectively developed in order to solve a problem so as to socially include those involved, ensuring quality of life and environmental gains. They also highlight the low cost usually related to the availability of local materials included in the assembly in this conceptual universe, as labor and time invested must also be considered as social capital employed in its development; replication and reapplication concepts when it comes to reproduction from a step-by-step basis and the reproduction of ST in broader parameters which enable its improvement, including methodological adaptation and incorporating other materials; and that the practices identified as ST consequently have a "step-by-step" process, a development methodology and not necessarily a protocol.
The proposed study was directed to a specific biodigestor model called "sertanejo biodigestor," resulting from an adaptation proposed by the NGO Diaconia to the Indian model with technology used in plate cisterns widely spread across the semi-arid region (Mattos and Júnior, 2011, p. 7).

The innovative aspects proposed by the NGO Diaconia to adapt the technology included the materials for constructing the equipment. However, they must be analyzed from the point of view of construction practicality, results in biogas production and total costs of the equipment. According to the NGO Diaconia (2016), there is a significant number of Sertanejo biodigesters deployed in the Agreste region of Pernambuco, and part of this equipment is totally or partially deactivated. This fact leads to the need for identification of the weaknesses regarding the adaptation to the dynamics of farming families with the technological innovation that gave rise to one of the focuses for research.

In a complementary way, the high cost of LPG can compromise the family income, essentially of the farming families, in view of their non-fixed income associated with the productive processes when it is not linked to social security and complementary programs for income distribution. According to the data presented by the NGO Diaconia, a farming family spends $9.32 \%$ of the minimum wage on the purchase of LPG monthly, or collects $21.06 \mathrm{~kg}$ of wood to prepare food. It is then a problem related to family income and that the biodigester can effectively contribute with biogas (methane) to the detriment of the use of LPG. However, the question is what is the actual contribution of the biodigester when it comes to increasing family income? In economic terms, it is necessary to check whether the biodigester is really capable of promoting economic gains, considering the references presented by the NGO Diaconia (s.d., p. 8), suggesting that the use of the biodigestor can provide families with savings in monthly expenses equivalent to one and a half canisters of LPG, equivalent to $10 \%$ of the minimum wage.

Therefore, the aim of this study was to evaluate the use of the Sertanejo biodigester by farming families in the Agreste region of Pernambuco as a social technology for producing cooking gas, as an alternative source of energy and to mitigate climate change. It also aimed to identify economic and social elements that contribute to disseminating this technology as an alternative for cooking gas production to replace the use of firewood, charcoal and LPG for domestic activities in the context of family farming in the semi-arid region.

The study starts from two basic hypotheses: the use of the biodigester social technology provides an increase in the income of farming families due to a reduction in the use of LPG, avoids the use of firewood and charcoal and contributes to producing biofertilizer for the family's crops; the continuous non-use or deactivation of the biodigester is related to a lack of raw material, requirements in equipment maintenance (which takes a lot of work) and/or the lack of labor to maintain the equipment. 


\section{Material and methods}

\section{Study area}

The study considered the municipalities of Bom Conselho, Caetés, Jupi and São Bento do Una, located in the Agreste mesoregion of Pernambuco as its geographic focus (Figure 1), taking the quantity of biodigesters deployed in that territory belonging to the participating families of the Biodigestor Project as a reference, as executed by the NGO Diaconia.

The Sertanejo Biodigestor (Figure 2) is described by Mattos and Júnior (2011) from the Sertanejo Biodigestor Manual, a component of the Sustainable Land Management Project in Sertão, a publication of the Dom Helder Câmara Project $(P D H C)$. Another reference found for this type of biodigester is the NGO Diaconia's booklet, 12 steps to build a biodigestor as a product of the "Biodigestors: A Social Technology in the National Rural Housing Program" project, with support from the Caixa Socioenvironmental Fund (FSC). As shown in the two manuals mentioned above, the Sertanejo biodigester adopts the same principles as the Indian model, meaning it is a structure formed by an inlet box (herein referred to as the cargo box), a storage tank (also called the biodigestor tank or main tank), a gas storage hood coupled with a structure to capture the gas produced and a waste outlet box (herein referred to as discharge box). It is observed that the main difference between this model and the others is the type of material used for its construction as a way of adapting to small rural properties. While the Indian and Chinese models use masonry to build the fermentation tanks, in this model the construction is made with cement plates using the same construction principle as the Precast Plate Cisterns in cylindrical shape, according to Figure 3. The cistern is cylindrical in shape, covered and semi-buried. Its operation provides for the capture of rainwater using the roof of the house, which drains the water through gutters (ASA, 2021).

The waste input and output boxes do not differ in the type of material used, only in the format. On the other hand, for the hood or gasometer, which is made of metal in the Indian model and with masonry in the Chinese model, the decision was to adopt a PVC box normally used for water storage in an inverted way in the Sertanejo model, which receives a zinc and earth structure on top to act as a counterweight. The way the gas is captured is another great differential, as a 20 -liter bottle adapted to receive and distribute the gas is used.

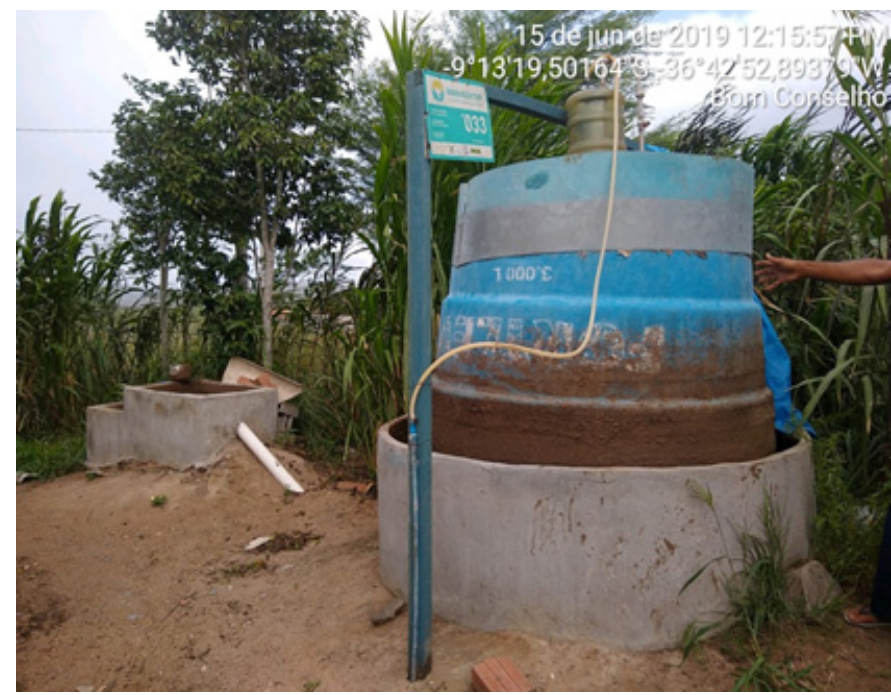

Figure 2 - Sertanejo biodigester with maximum biogas load. Angico Site, Bom Conselho-PE, by Wanderley Nunes and Cláudio Almeida, 2020.

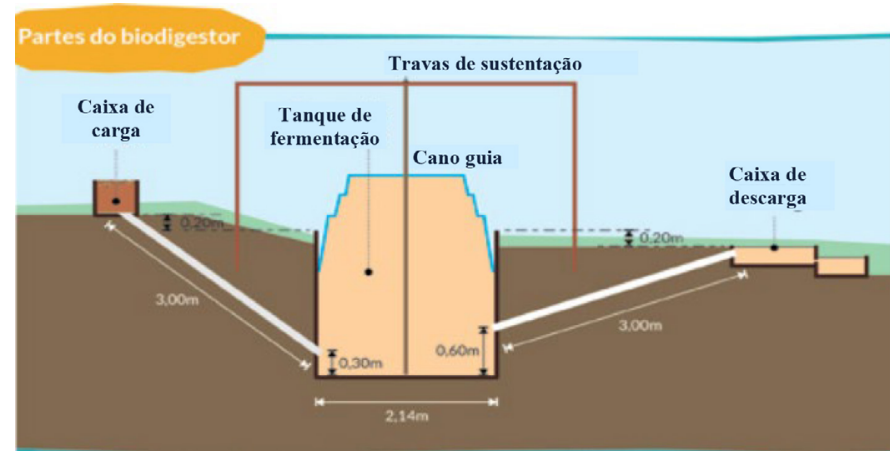

Figure 3 - Parts of the Sertanejo Biodigestor.

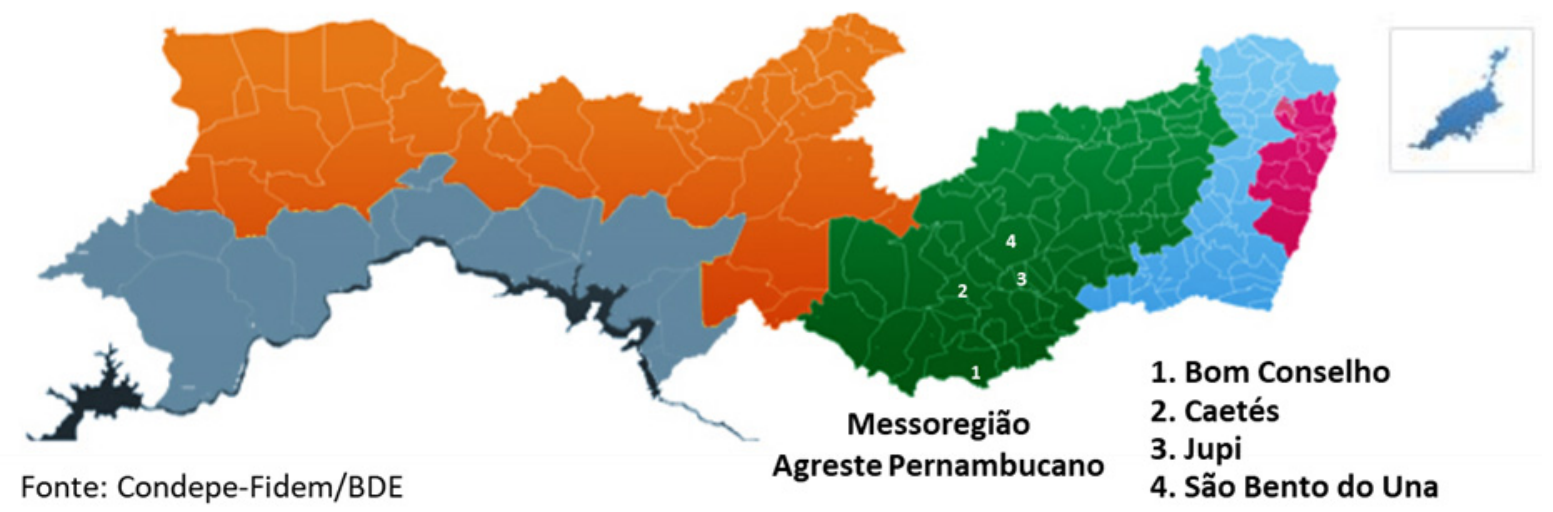

Figure 1 - Geopolitical division map of Pernambuco. 
By presenting the results of the work developed by the Network of Biodigesters for Latin America and the Caribbean (RedeBioLAC) to identify barriers and mechanisms to overcome them, aiming at the massification and democratization of medium and small scale biodigesters in Latin America and the Caribbean (LAC), Herrero et al. (2016) emphasize the need to adapt the technology to the user (and not the other way around), and that the visibility and dissemination of biodigesters must fully consider their environmental aspects of changing the production and energy matrix and self-sufficiency for the producer.

According to the Diaconia NGO (s.d.), the "Sertanejo Biodigestor" has the following benefits, as shown in Chart 1.

It is important to consider that biofertilizers are a by-product of the effluents from the biodigester, the digestate, which, according to Nicoloso et al. (2019, p. 122), should follow the fundamental principles of fertilizer management and soil fertility already established and constantly refined by research.

\section{The nature of this study}

According to the definitions adopted by Gerhardt and Silveira (2009, p. 31), this study is classified as exploratory regarding its objectives, as it is the method which aims to provide greater familiarity with the problem with a view to making it more explicit or build hypotheses. It is configured as qualitative and quantitative in its approach, and documentary and field data were used based on interviews and questionnaires as the data source. Non-probabilistic sampling was also used, defended by Guimarães (2008) as a convenience sample formed by elements that the researchers gathered because they had them, or the researchers makes use of data which are more within their reach, which in this case is access to families with biodigesters.

\section{Chart 1 - Benefits pointed out by the NGO Diaconia with the use of the} Sertanejo Biodigestor.

\begin{tabular}{|c|c|}
\hline Where & Benefits \\
\hline $\begin{array}{l}\text { In the } \\
\text { environment }\end{array}$ & $\begin{array}{l}\text { - Firewood is not taken from the forest for cooking } \\
\text { - Contributes to reducing deforestation and the effects } \\
\text { - Prevents methane gas released by the natural } \\
\text { combustion of animal manure from being released } \\
\text { into the atmosphere }\end{array}$ \\
\hline On health & $\begin{array}{l}\text { - The biogas produced when used in the stove does } \\
\text { not release smoke, preventing respiratory problems } \\
\text { - It contributes to the health of animals by collecting } \\
\text { waste and cleaning corrals and pigsties, reducing } \\
\text { infestation by worms and flies }\end{array}$ \\
\hline $\begin{array}{l}\text { On the Family } \\
\text { income }\end{array}$ & $\begin{array}{l}\text { - Saves a bottle and a half of LPG gas per month } \\
\text { - Produces organic fertilizer and biofertilizers }\end{array}$ \\
\hline In Agriculture & $\begin{array}{l}\text { - Produces natural fertilizers: biofertilizer and tanned } \\
\text { manure, which can increase soil fertility and improve } \\
\text { production }\end{array}$ \\
\hline
\end{tabular}

Source: Diaconia (s.d.).
Sample

The population targeted by this study is part of the universe of farming families residing in houses financed by the PNHR of Caixa Econômica Federal (CAIXA), benefiting from the implementation of 395 biodigester units in 39 municipalities of 06 states of the Federation: Bahia, Goiás, Minas Gerais, Pernambuco, Rio Grande do Sul and Santa Catarina. A total of 24 families in Bahia were benefited; 61 in Minas Gerais; 50 in Goiás; 52 in Santa Catarina; 67 in Rio Grande do Sul; and 141 in Pernambuco. The project concentrated its actions in the municipalities of Bom Conselho, Caetés, Jupi and São Bento do Una, in the state of Pernambuco, all belonging to the Agreste mesoregion of Pernambuco, with the goal of implementing 132 units (Diaconia, 2016, p. 8).

From a sampling point of view, a sample based on these data was estimated, which met the expectation of verifying the abandonment rate of using the biodigesters and measuring their impact on family dynamics. Therefore, the finite population of 132 family units of biodigesters implemented in the Agreste mesoregion of Pernambuco was considered, and the probability of continuous non-use or deactivation of the biodigesters was estimated in 15\%, with a $95 \%$ confidence level, adopting the associated variable of 1.96 and a standard sampling error of 5\%. Thus, applying the Equation 1 for sample definition suggested by Meunier et al. (2001), we would need to apply 75 interviews ( $57 \%$ of the total population), and 83 samples were collected during the field visit process, reaching a representation of $63 \%$ of the families using the biodigester.

$$
\mathrm{n}=\frac{\mathrm{N} \cdot \mathrm{Z}^{2} \cdot \mathrm{p} \cdot(1-\mathrm{p})}{\mathrm{Z}^{2} \cdot \mathrm{p} \cdot(1-\mathrm{p})+\mathrm{e}^{2} \cdot(\mathrm{N}-1)}
$$

\section{Where:}

$\mathrm{n}=$ calculated sample (size);

$\mathrm{N}=$ population (families with biodigesters) (132);

$\mathrm{Z}=$ standardized normal variable associated with confidence level 95\% (1.96);

$\mathrm{p}=$ probability of biodigester deactivation (\%) (0.15\%);

$\mathrm{e}=$ sampling error $(5 \%$ standard $)(0.05 \%)$

\section{Data used in the study}

Semi-structured interviews, systematic observations and photographic records were used as the primary data collection techniques carried out from the field survey. The semi-structured interview was the main instrument to respond to the general objective, as well as to seek subsidies which would allow confirming or denying the presented hypotheses. Thus, data collection took place in the municipalities of Caetés, Jupi and São Bento do Una, maintaining distinct audiences, defined by: families participating in the biodigestor project in the Agreste region of Pernambuco; community leaders; families with consolidated use of the Sertanejo biodigester in the Sertão do Pajeú region, 
and the NGO Diaconia's technical team members. Descriptive statistics according to Guimarães (2008) were used to treat the collected data.

\section{Results and Discussion}

This topic is dedicated to systematizing and interpreting the data generated in the study. The analysis addresses aspects related to the use of technology, economic and environmental impacts, and the role of social organizations in the process of mobilizing families.

Quadros (2009) defends the use of the biodigester in family farming in the Semi-arid region as a means of overcoming energy shortages resulting from economic and environmental impacts as a consequence of the use of firewood and cooking gas. In this perspective, he suggests the biodigester as an alternative to use goat and sheep manure for energy generation (biogas) and fertilizer (biofertilizer), and concludes (among other issues) that it has a high potential for replication in family farming as it has a high cost/benefit ratio with the generation of biogas and organic fertilizer. The data that we will see below corroborates this statement, as they present important subsidies for the debate on using the biodigester in family farming, especially in the semi-arid region, related to the acceptance of the technology, dimensioning biogas production at the expense of the available raw material, in addition to bringing elements related to environmental, economic and social aspects with the use of biodigesters in the family agroecosystem.

It is important to understand that the following data refer to a study dimensioned by three associated variables: family farming, semi-arid and Sertanejo biodigester as a proposal for a technology to produce cooking gas in the context of family farming, therefore constituting a very peculiar context. In any case, based on the work developed by Herrero et al. (2016) with the purpose of giving visibility to the positive impacts of the use of the biodigester in sustainable family, community and productive development, it was possible to identify several experiences in Latin America which corroborate the results presented in this work. In addition, those conducted in the state of Ceará, by Barros et al. (2020) make reference to the work of the NGO Cetra, which built around 300 biodigesters in 20 municipalities in Ceará between 2015 and the first quarter of 2020 .

It should be noted that Non-Governmental Organizations (NGOs) play a leading role in the work of multiplying the use of biodigesters for producing biogas in the context of family farming, such as the work developed by Diaconia and Cetra, who, together, are responsible for implementing more than 600 Sertanejo biodigesters, mainly in the semi-arid region of the Northeast.

\section{Implementation and use of the biodigester}

The data collected indicate that a considerable part of the families (around 25\%) was unable to specify the date that the biodigester was installed on the property. However, it was possible to register that the first units implemented in the surveyed municipalities (about 2\%) date from the end of 2014. The vast majority (around 71\%) was implement- ed between the period from January 2015 to October 2016; this means a majority of families had three to four years of experience with the use of this technology, considering the end of 2019 as a reference. One third of the families (32.5\%) had their biodigesters deactivated (at the end of 2019) and another group (about 22\% of the sample) was not using the produced biogas. Therefore, these numbers can be considered quite expressive, especially when the economic and environmental appeal associated with the biodigester technology is highlighted.

According to Herrero et al. (2016), the work developed by the NGO PROSUCO in Bolivia, with the implementation of 40 biodigesters in 10 municipalities, enabled approximately $50 \%$ to be consolidated as a reference in the supply of bio-inputs and in research and innovation. According to Jiménez and Zambrano (2018), the Technological Institute of Costa Rica installed 38 biodigester units in 4 rural communities in the city of Limón in Costa Rica, intended for the treatment of organic waste, mainly from swine, and used only as an energy source for food preparation, where 28 remain active, while 10 units (26\%) are disabled due to lack of interest from families or due to system breakdowns.

Aspects related to the advantages and disadvantages of using the biodigester from the perspective of families who deal directly with the technology are diverse, but point to a certain consensus. The data systematized in Table 2 clearly shows how the economic issue stands out as an advantage for the use of the biodigester, being pointed out by $94 \%$ of the families as something important, followed by practicality (43\%) and abundant production of biogas (12\%). This is also the opinion of the reference families of Sertão do Pajeú, where the majority ( $80 \%$ of the sample) claim to have decided to implement the biodigester due to aspects related to reducing expenses with the purchase of LPG gas associated with its high cost.

About $90 \%$ of the sample referred to savings or improvement in family income when asked about the advantages of using the equipment. The interviews carried out with community leaders in the municipalities also follow the same opinion. The economic factor stands out as the main advantage for most respondents, in addition to reporting the fact that it is easy to handle and performs well in cooking food.

The opinion of the families in the Pajeú Region does not differ from the narrative presented above, as $90 \%$ of them refer to issues related to the economy when justifying that they are no longer able to purchase gas. It was also the reason why $80 \%$ of them decided to implement it considering the difficulties of finding firewood, aiming to replace the use of firewood and charcoal, and also considering the fact that it is a clean, non-polluting gas as an advantage.

A work developed by Silva and Correia (2020) in Oeste Potiguar considering a universe of 21 families refers to the degree of acceptability of the Sertanejo biodigester technology used for more than two years, with $42 \%$ of them in use for more than five years, and indicating that $100 \%$ of the families rated the technology as great or good.

Families point out issues related to work regarding equipment maintenance $(28 \%)$ and the lack of waste for supply (37\%) in the field 
Table 2 - Advantages and disadvantages in the use of the biodigester presented by families in the municipalities of Bom Conselho, Caetés, Jupi and São Caetano, 2019.

\begin{tabular}{|l|c|c|}
\hline Evaluated aspects & Absolute Frequency & Percentage \\
\hline Advantages & 78 & \\
\hline Economical & 36 & 94.0 \\
\hline Pratical & 10 & 43.4 \\
\hline Abundant gas & & 12.0 \\
\hline Disadvantages & 23 & 27.7 \\
\hline Very hard work & 31 & 37.3 \\
\hline Difficulty collecting waste & 2 & 2 \\
\hline Production decreases in winter & & \\
\hline
\end{tabular}

Source: Field research (2020).

of negative aspects. In this sense, the vast majority refers to the labor required for management as the main disadvantage of use, since the search for waste outside the property requires time and competes with other activities in the production system.

In terms of disadvantages, $65 \%$ of the families interviewed in Sertão do Pajeú assert that they have no problems or difficulties handling the biodigester. They mention three elements regarding the negative aspects: dryness or cracking in the piping leading the gas to the stove (15\% of the sample); water accumulation in the pipe (10\%); and a lack of sufficient animals to produce raw material ( $10 \%$ of the sample). On a smaller scale, they cite issues related to insufficient water to feed the equipment, difficulties in transporting the manure and damage to the container for filtering the gas (drying). This last difficulty was the subject of changes proposed by the NGO Diaconia in the filtration system, circumvented by replacing the water canister with more resistant PVC material (Diaconia, 2016).

Knopki (2015) describes that biogas can be used to produce electric, thermal, fuel gas and vehicle fuel, as well as the main characteristic of its flexibility as an advantage, while the disadvantage is due to its complexity related to factors such as controlled production, a value chain which is considered complex, and because it is an explosive combustible gas that requires rigorous control, monitoring and investment in safety issues.

The group of families with deactivated or unused biodigesters basically point to three elements as the cause:

1. that the biodigestor does not work (41\%), without specifying the reason;

2. they do not need the biodigester (37\%);

3. the supply is low.

Of these aspects, items (a) and (c) are related to surmountable causes; however, item (b) points to something directly related to aspects not identified before the implementation of the biodigester, which is the family's need for the technology.
Community leaders point out possible causes for disabling the biodigester as the lack of interest from the families, the lack of manure to feed the biodigester, the lack of maintenance and the lack of technical assistance. Families interviewed in Sertão do Pajeú (with longer use of biodigesters) highlight two aspects related to not using the biodigester: the lack of interest or commitment, as cited by $65 \%$ of respondents; and the fact of not having animals to produce raw material, cited by $40 \%$.

Still regarding item (c), it is observed that the raw material used to supply the biodigester basically has two sources: cattle and swine. Considering that $34 \%$ of the families raise goats and sheep, and that $71 \%$ declare raising birds, the results clearly indicate that the manure from these animals is not used as raw material for feeding the biodigester. However, it is observed that there is a strong relationship of dependence with raising cattle, as $82 \%$ of the families use the manure of these animals as an energy source, with part of them (20\%) being associated with swine manure. The latter is responsible for supplying raw material to $7 \%$ of the families, and it increases its contribution to $28 \%$ in the families when associated with cattle (Table 3).

The amount of raw material (manure and water) used is directly related to the dynamics of household use. Thus, it was possible to identify families using $10 \mathrm{~kg}$ to $400 \mathrm{~kg}$ of raw material per week, with the majority (84\%) using up to $62 \mathrm{~kg}$ per week, with an average of $55 \mathrm{~kg}$ per family (Graph 1).

Table 3 - Sources of raw material for the biodigester in families in the municipalities of Bom Conselho, Caetés, Jupi and São Caetano, 2019.

\begin{tabular}{|l|c|c|c|}
\hline Source & $\begin{array}{c}\text { Absolute } \\
\text { Frequency }\end{array}$ & Percentage & $\begin{array}{c}\text { Accumulated } \\
\text { Percentage }\end{array}$ \\
\hline Cattle and Swine & 17 & 20.5 & \\
\hline Cattle & 50 & 60.2 & 82 \\
\hline Cattle and Whey & 1 & 1.2 & \\
\hline Swine & 6 & 7.2 & 100 \\
\hline Uninformed & 13 & 10.8 & \\
\hline
\end{tabular}

Source: Field research (2020).

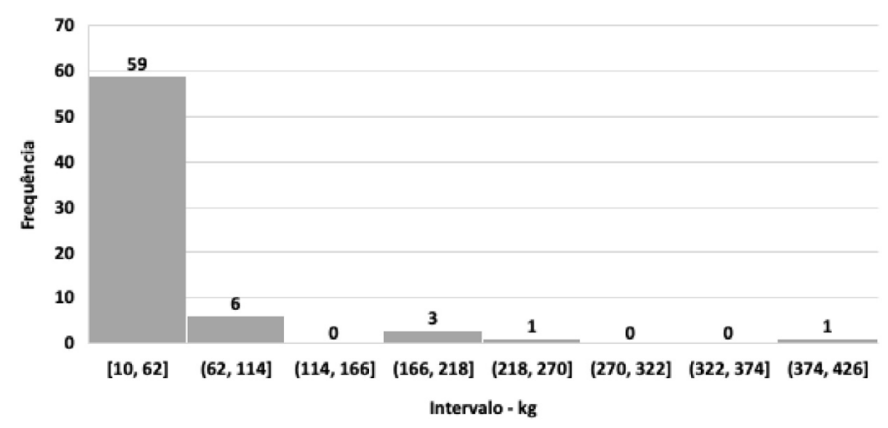

Graph 1 - Amount of raw material used to supply the biodigester by families in the municipalities of Bom Conselho, Caetés, Jupi and São Caetano, 2019.

Source: Field research (2020). 
An important element in the context of families in the Semi-arid region is the use of water, as the biodigester requires a lot of water for to fully operate, due to the characteristic of biogas production from anaerobic fermentation. Data collected on water use indicate an average of 40 liters per week; however, some families use up to 300 liters of water per week. This indicates a proximity to the ratio of $1 \mathrm{~kg}$ of raw material to 1 liter of water, as recommended in the construction manuals for the Sertanejo biodigester.

There is an important competition with the main source for domestic consumption when identifying the water source used, which is the cistern, and occurs in $54 \%$ of the families. The other sources are traditionally employed for different uses, especially for animal watering. However, the contradictory fact is that, despite the fact that most families have the cistern as a source of water for feeding the biodigester, only $28 \%$ claim that the water used is potable (i.e. suitable for human consumption), while $77 \%$ claim to use water for general purposes, although some may fall into both types.

Plate cisterns have recently gained prominence in family agroecosystems, with the implementation of the One Million Cisterns Program $(P 1 M C)$, aiming at capturing and storing rainwater for human consumption. Data indicate that there were 626,791 units implemented in all semiarid states until May/2019 (ASA, 2019) under the P1MC. A study evaluating the program in 2010 presents some findings which are in line with the data presented regarding the cistern water use:

- the physicochemical characteristics of the waters stored in the cisterns indicate that these do not come from rainwater collection, but from other alternative sources of supply;

- $79.54 \%$ of the samples were considered unrestricted for use by beneficiary families;

- the management is adequate in $82.8 \%$ of the interviewed families, while it is inadequate in $15.1 \%$, with the main problem being the poor state of conservation of the cisterns;

- few households (approximately 19.1\%) only use the cistern as the main source for domestic water;

- $\quad$ stored water lasts 12 months in just over a third of households (36.4\%), while stored water lasts for a maximum of six months for $26.2 \%$.

This last data has an important meaning considering that the more uses that depend on the accumulated water of the cistern, the shorter the available water time (Brasil, 2010, p. 151).

Given the specificities of the Semi-arid region in relation to water availability, any technology that presents a demand for consumption which will effectively compete with water for domestic use must be carefully analyzed. In the specific case of the biodigestor, it deserves technical deepening regarding the possibility of its interconnection to a system for the reuse of greywater, as a water source for the fermentation process, as well as toilet waste as a way to use organic matter for the biodigester.
Part of the water used to facilitate the fermentation process is drained in the form of biofertilizer, which can be used as liquid fertilizer on crops. The data indicate that this guidance was well captured by the set of families, as $84 \%$ of the families with a functioning biodigester claim to use the biofertilizer for some type of crop.

\section{Economic and social aspects}

It was possible to identify that the biodigesters resulted from the relationship that the families maintain with the local Community Association in $75 \%$ of the families, and with the Union of Family Farmers Workers in $64 \%$ of the cases, indicating that the relationship with these organizations takes place simultaneously for some. Some families (9\%) refer to Cooperativa de Habitação Rural da Agricultura Familiar, Assentamentos da Reforma Agrária e Comunidades Tradicionais LTDA (Rural Housing Cooperative of Family Farming, Agrarian Reform Settlements and Traditional Communities LTD) (ABEMORAR) the partner organization of the NGO Diaconia NGO that carried out the project in some municipalities.

The biodigester implementation resulted from the action of a project co-financed with public resources through the Caixa Econômica Federal Social and Environmental Fund in all the families surveyed, and they did not imply practically any financial cost. Only a small part claims to have made any investment in paying for the labor of a bricklayer's assistant, with values between $\mathrm{R} \$ 150$ and $\mathrm{R} \$ 250$. This is also the narrative of the families in the Pajeú Region, where virtually all the biodigesters resulted from the action of the NGO Diaconia. In this case, the families claim to have only contributed with labor help such as digging the hole and building the biodigester.

When asked what the cost of a biodigester would be, $71 \%$ of the sample said they did not know and 29\% referred to a cost ranging from $\mathrm{R} \$ 2,500$ (two thousand five hundred reais) to $\mathrm{R} \$ 8,000$ (eight thousand reais), with an average cost of around $\mathrm{R} \$ 3,900$ (three thousand nine hundred reais). According to the NGO Diaconia (2020), as indicated in the qualified interview with members of its technical team, the costs of mason labor, digging the hole, installation, materials and technical monitoring for a biodigestor unit are around $\mathrm{R} \$ 4,000$ (four thousand reais), meaning they are comparable with the average obtained according to information from the families. Here it is worth noting that a family would take between 48 and 67 months (4 to 5 years) to have the investments reversed at a cost of R $\$ 65$ per LPG gas canister by taking as a reference this cost per biodigester and the equivalent biogas production capacity between 0.92 and 1.28 canisters/month.

The income sources and expenses of families were then analyzed in order to understand the composition of the family income, considering that this is not a deepening of the various elements that make up their income, from the perspective brought by Mattos (2017) when discussing the pluriactivity and multifunctionality of family farming as an important element in aggregating income. Thus, the information col- 
lected from the questionnaires enables comparisons and dimensioning of the impact of biogas use on the family economy within the proposed purpose of the work and drawing parallels with the main sources of income, as identified in Table 4.

A first piece of evidence is that the contributions resulting from the Bolsa Familia Program and the Rural Retirement Program constitute the two main sources of income, since the two do not add up per family. Then there are revenue contributions from agricultural and livestock activities, present in $48.2 \%$ of families, especially milk (18\% of families). Furthermore, the participation of non-agricultural activities (39.8\% of families) is not less important, and is mostly related to renting labor.

The survey on the effective use of income had the purpose of identifying the main expenses of the families, focusing on the main consumption elements and giving total freedom to the families to mention the main expenses with the residence. The results enable us to identify that spending on food is the most cited ( $95.2 \%$ of families), followed by electricity (90.4\%) and gas, charcoal and firewood (76\%), thus forming the tripod of the main expenditure elements cited by families, followed by transport (19\%), health (16\%) and other expenses (12\%), as shown in Table 5.
The three main energy sources traditionally used for cooking food in addition to biogas were analyzed, introduced as an alternative to the use of LPG gas. It is noteworthy that the use of LPG gas is still dominant even in the context of families who have adopted the Sertanejo biodigester technology for biogas production, as 54\% of families still use it as the only source of energy for kitchen activities, while another $25 \%$ alternate its use with biogas, which indicates that $79 \%$ of families maintain their LPG gas consumption after installing the biodigesters. Thus, the use of biogas as the only energy source for kitchen activities is present in only $17 \%$, but it can be said that $42 \%$ of families use this energy source, even if one does that less frequently than another, which will be detailed further on.

The data presented in Table 5 clearly show that the main expenses of families occur with food and health, reaching more than $50 \%$ of the monthly average. Expenditures on gas, firewood and charcoal represent only $5 \%$ of the average monthly expenditures; however, when related to income transfer, retirement and pension programs (Table 4), these expenditures represent $8.9 \%$ of these revenue sources, increasing its impact considerably when compared to the income from the Bolsa Família Program, which represented $28.4 \%$ of the average obtained. These same data can represent $14 \%$ and $25.5 \%$ when related to the av-

Table 4 - Main sources of income for families in the municipalities of Bom Conselho, Caetés, Jupi and São Caetano, 2019.

\begin{tabular}{|c|c|c|c|c|}
\hline \multirow{2}{*}{ Income source } & \multirow{2}{*}{ Absolute Frequency } & \multirow{2}{*}{ Relative Frequency } & \multicolumn{2}{|c|}{ Mean income (by type) } \\
\hline & & & Monthly & Annual \\
\hline Transfer Income/Benefits/Pension & 73 & $95.2 \%$ & 682.87 & $8,194.49$ \\
\hline Agricultural & 40 & $48.2 \%$ & 438.23 & $5,253.80$ \\
\hline Non-Agricultural & 33 & $39.8 \%$ & 239.74 & $2,876.85$ \\
\hline Bolsa Família Program & 54 & $65.1 \%$ & 215.00 & $2,795.00$ \\
\hline Rural retirement & 24 & $28.9 \%$ & 998.00 & $12,974.00$ \\
\hline Hired labor & 22 & $26.5 \%$ & 48.63 & 583.55 \\
\hline Selling milk & 15 & $18.1 \%$ & 471.33 & $5,656.00$ \\
\hline Selling cheese & 5 & $6.0 \%$ & 620.00 & $7,440.00$ \\
\hline Formal employment & 3 & $3.6 \%$ & $1,154.11$ & $13,849.33$ \\
\hline Selling eggs & 2 & $2.4 \%$ & 57.33 & 688.00 \\
\hline Cleaning services & 1 & $1.2 \%$ & 300.00 & $3,600.00$ \\
\hline Selling candy & 1 & $1.2 \%$ & 100.00 & $1,200.00$ \\
\hline Craftsmanship/handicrafts & 1 & $1.2 \%$ & 50.00 & 600.00 \\
\hline Help from relatives & 1 & $1.2 \%$ & 29.17 & 350.00 \\
\hline Pension & 1 & $1.2 \%$ & 998.00 & $11,976.00$ \\
\hline
\end{tabular}

Source: Field research (2020). 
Table 5 - Main expenses of families benefiting from biodigesters in the municipalities of Bom Conselho, Caetés, Jupi and São Caetano, 2019.

\begin{tabular}{|l|c|c|c|c|}
\hline Type of expense & Absolute Frequency & Relative Frequency & Mean monthly expense & Participation \% \\
\hline Food & 79 & $95.2 \%$ & 464.94 & $37 \%$ \\
\hline Electricity & 75 & $90.4 \%$ & 49.51 & $5 \%$ \\
\hline Gas/Coal/Firewood & 63 & $75.9 \%$ & 61.05 & $9 \%$ \\
\hline Transport & 16 & $19.3 \%$ & 118.75 & $19 \%$ \\
\hline Health & 13 & $15.7 \%$ & 10.75 & $1 \%$ \\
\hline Clothes & 2 & $2.4 \%$ & 30.00 & $2 \%$ \\
\hline Leisure & 1 & $1.2 \%$ & 333.00 & $26 \%$ \\
\hline Other expenses & 10 & $12.0 \%$ & \\
\hline
\end{tabular}

Source: Field research (2020).

erage revenue from agricultural activities and non-agricultural activities, and expenses on gas, firewood and charcoal, respectively.

According to Diaconia (2020), each family traditionally spends about $10 \%$ of the minimum monthly wage on the purchase of butane gas, which means something around $\mathrm{R} \$ 104.50$ in current values. It is therefore assumed that the replacement of these sources with the continuous use of biogas would generate savings for families, and would impact them in different ways according to their revenue composition; however, by following mathematical logic, there would be greater significance for families with a lower monthly revenue average.

The financial impact of using biogas is diluted as alternatives and the mean monthly household income increase. Consequently, the use of biogas in these cases to replace the use of LPG gas, firewood and charcoal generates savings that range from 4 to $5 \%$ of the monthly average, which may not be very attractive for introducing a technology such as the biodigester due to its daily management dynamics, as discussed above.

Table 6 also indicates that there is important room for growth in the use of the biodigester from the perspective of reducing expenses on gas, firewood and charcoal for families with little income diversification, but especially for those who depend on the Bolsa Família Program. A considerable percentage still uses butane gas as the only source for cooking food, followed by a group of families who associate biogas with LPG gas, and finally a smaller group (16.9\%), who only use biogas. It is noteworthy that when excluding families with the biodigester disabled, the percentage of those who only use biogas to cook food rises to $25 \%$. In any case, it is important to highlight that $42 \%$ of the total sample uses biogas, and again, the percentage of families with active biodigesters who use biogas in domestic activities increases to $62.5 \%$ when extracting the deactivated biodigesters.
The firewood used is removed from the property in $87 \%$ of the cases; however, the type of firewood was not studied in depth, although some families insisted on informing that it was forest fragments or dry firewood, without the need for felling trees. Another important element is that $82 \%$ of the families say they use firewood weekly, characterizing a very present dynamic in these families. In this sense, a study by Specht (2012) indicates that more than $65 \%$ of the respondents use firewood in their homes in different degrees of intensity, at least once a month or every day, and also reveals that $40 \%$ of the respondents point to saving gas and money among the reasons chosen for regarding the use of firewood, and another $40 \%$ refer to faster cooking due to its high calorific value.

Thus, it is possible to suggest that the best strategy for introducing the technology to families with a higher income range may not be by convincing them of the economic impact, especially if the use of biogas is only associated for cooking food. Therefore, it is necessary to show more forcefully the environmental gains that the technology can offer, and especially to associate other uses of biogas in the production system or in residential activities, which can enable them to expand their participation in the reduction of expenses and consequently contribute to the family income.

By making a comparison with the group of families interviewed in Sertão do Pajeú, it is observed that the association of biogas with other energy sources for cooking food can remain over time, even on a smaller scale. This is because $55 \%$ of families say they use firewood or gas occasionally when it comes to the need to use large utensils for cooking food (related to receiving visits), or when there are problems with equipment maintenance, which is treated as an emergency. When it comes to the use of butane gas associated with biogas, there are reports mentioning the use of 1 canister every two or three months, 1 to 2 canisters per year or 1 canister every 4 years. In any case, $20 \%$ of 
Table 6 - Energy sources used by families in the municipalities of Bom Conselho, Caetés, Jupi and São Caetano, 2019.

\begin{tabular}{|l|c|c|c|c|c|}
\hline \multicolumn{1}{|c|}{ Energy source } & Unit & Absolute Frequency & Percentage & Mean monthly consumption & Mean monthly expense (R\$) \\
\hline Canister (without Biogas) & Canister & 45 & $54.2 \%$ & 0.86 & 52.93 \\
\hline Canister (+ Biogas) & Canister & 21 & $25.3 \%$ & 0.76 & 33.13 \\
\hline Only Biogas & Canister & 14 & $16.9 \%$ & 1.0 & - \\
\hline Coal & $\mathrm{Kg}$ & 38 & $45.8 \%$ & 25.0 & 22.00 \\
\hline Firewood & $\mathrm{m}^{3}$ & 28 & $33.7 \%$ & 1.9 & - \\
\hline
\end{tabular}

Source: Field research (2020).

the families claim to use only biogas, which is a number close to that obtained from families in the Agreste region of Pernambuco.

Impact studies of the implementation of 265 biodigesters in the Yucatán Mayan communities in Mexico showed a 97\% reduction in the use of firewood in households, placing biogas as the main energy source and identifying an increase in agricultural production by more than $60 \%$ of the families, resulting from the use of the biofertilizer. A small milk producer in Costa Rica implemented its biodigester and replaced $40 \%$ of the diesel used in its boiler, achieving a return on its investment in less than 2 years. ASPROINCA (Asociación de Productores Indígenas y Campesinos de Riosucio Caldas) in Colombia has more than 250 biodigesters installed in its operating territory from its own revolving fund and with the training of Community Promoters (Herrero, 2016).

Work developed by Silva and Correia (2020, p. 8) in Oeste Potiguar found that firewood was the main energy source for $66.7 \%$ of the families before the biodigester purchase; $33.3 \%$ used cooking gas and another $14.3 \%$ used charcoal. This data reveals how much impact introducing the biodigester can have as a gas supplier for cooking food, considerably reducing the use of wood from the caatinga for both direct consumption and for charcoal production, as both were present in $81.9 \%$ as power supply.

As shown in Table 7, the average usage time of a gas canister was around 30 days, with this period corresponding to $50 \%$ of the families; others (28\%) consume the same amount of gas for a period between 45 and 60 days. The unit cost of a gas canister ranged between $\mathrm{R} \$ 60 / 75$ in the studied period (Nov./18 to Jan./20). However, there is an additional cost for $63 \%$ of the families, as they buy gas in the city, while $37 \%$ buy it in the community and may not have the additional transportation allowance. When asked about the advantages and disadvantages of using LPG gas, practicality and agility are the main advantages for $70 \%$ of families; while the high cost is the main disadvantage for $75 \%$ of families.

Returning to the study developed by Jiménez and Zambrano (2018), which analyzed biogas consumption, it was observed that the average daily biogas consumption in a universe of 28 biodigest-
Table 7 - Usage time of the LPG gas canister by families in the municipalities of Bom Conselho, Caetés, Jupi and São Caetano, 2019.

\begin{tabular}{|l|c|c|}
\hline Usage time (days) & Absolute Frequency & Percentage \\
\hline 20 & 1 & 1.5 \\
\hline 25 & 1 & 1.5 \\
\hline 30 & 34 & 50.0 \\
\hline 45 & 4 & 5.9 \\
\hline 60 & 15 & 22.1 \\
\hline 90 & 8 & 11.8 \\
\hline 120 & 3 & 4.4 \\
\hline 180 & 1 & 1.5 \\
\hline 365 & 1 & 1.5 \\
\hline
\end{tabular}

Source: Field research (2020).

ers (active) in rural communities in the evaluated period (110 days of measurement) was $0.37 \mathrm{~m}^{3}$, with $50 \%$ of the consumption data found between 0.2 and $0.5 \mathrm{~m}^{3} /$ day. Regarding the economic impact, the study found that the use of firewood was present in $82 \%$ of the families at a cost of USD 19.50, thus obtaining a total annual value for the use of firewood of USD 438.30. Moreover, an investment of USD 306.27 per year occurred in the case of replacement of the LPG gas. Thus, the authors conclude that: obtaining and using biogas as an energy source does not represent a monetary cost for families, but rather some help which enables them to replace previously used fuels and chemical fertilizers, applying biofertilizer to improve income of their crops.

\section{Conclusions and Recommendations}

The use of social technologies in rural communities in the semi-arid region can meet immediate needs and promote important economic, social and organizational dynamic impacts on the community, enabling these families to understand and commit to environmental and social issues in their surroundings, making them local referenc- 
es. Training actions in the process of implementing these technologies, with a major role played by NGOs, open spaces for dialogue on practices and use of environmentally sustainable technologies, human rights, gender relations, and social participation, among others. Thus, the decision to use a simple source of clean energy to the detriment of the conventional energy matrix is a political and liberating posture, making its agro-ecosystem increasingly self-sustainable and independent of external resources. In this perspective, the results presented allow us to affirm the hypothesis that the use of the Sertanejo biodigestor social technology provides an increase in the income of farming families, influencing a reduction or even replacement of using LPG, and representing effective gains proportional to the income level of the families, in addition to biofertilizer production used in temporary and permanent crops, notably in forage cactus cultivation.

The hypothesis that the non-use or deactivation of the biodigester is related to the lack of raw material, requirements in equipment maintenance and/or shortage of labor to maintain the equipment is also confirmed, notably in relation to the raw material, as this is the reason most pointed out as the cause of the continuous non-use of the technology.

The existence of technology protection mechanisms is considered important, given the possibility of a loss of confidence in the proposed biodigester model due to its implementation without due care.
Thus, the following is recommended: not to deploy a biodigester in family units without livestock activities, under penalty of creating dependence on external sources; carry out preliminary studies on the family's demand for biogas, relating it to the potential of biogas production from the existing herd in order to establish a dynamic in accordance with the expected consumption; strengthen the arguments of economic impact for low-income families and highlight the arguments of environmental impact for families with more permanent sources of income, especially when not associated with agricultural activities; encourage the use of biogas associated with other activities in the production system, especially those dependent on conventional electricity, considering the construction of a biodigester with greater production capacity and using generators adapted to biogas use; establish dialogues with public agencies for technical assistance and rural extension and credit agents in order to incorporate the biodigester technology in financing lines from the environmental sustainability perspective; and always seek technical guidance for implementing the biodigester. It is a greatly useful device with environmental importance, but it needs to be well dimensioned and the installation of the gas pipes must be done by a professional with technical knowledge in the area.

\section{Contribution of authors:}

Souza, R.A.: Conceptualization, Methodology, Validation, Formal analysis, Research, Investigation, Resources, Writing - original draft. Lyra, M.R.C.C.: Supervision, Visualization, Writing - original draft, Writing - review \& editing, Project administration, Funding acquisition. Carvalho, R.M.C.M.O.: Supervision, Writing — original draft, Writing — review \& editing. Araújo Filho, J.C.A.F.: Conceptualization, Formal analysis, Methodology, Supervision, Visualization, Writing — original draft, Writing — review \& editing.

\section{References}

Articulação no Semiárido - ASA. 2019. Dados Gerais (Acessed July 7, 2021) at: https://www.asabrasil.org.br/mapatecnologias/.

Articulação no Semiárido - ASA. 2021. Modelo da tecnologia social de acesso à água $\mathrm{n}^{\circ} 1$. Cisterna de placas de 16 mil litros. Anexo da Instrução Operacional SESAN no 2, de 8 de agosto de 2017. Programa Cisternas. Recife.

Barros, G.C.; Farias Júnior, M.; Santos, M.N.F.; Nascimento, F.C.; Pascoal, C.D.; Duarte, M.D.S., 2020. Biogás e agricultura familiar no nordeste brasileiro: a experiência da ONG CETRA apoiada pela cooperação internacional no semiárido cearense. Revista RedBioLAC, v. 4, 39-43.

Brasil. 2010. Ministério do Desenvolvimento Social e Combate à Fome (MDS). Avaliação da sustentabilidade do programa cisternas em parceria com a articulação no semiárido brasileiro (ASA). Cadernos de Estudos Desenvolvimento Social em Debate, (13). Ministério do Desenvolvimento Social e Combate à Fome, Brasília, 240 pp.

Dagnino, R.; Brandão, F.C.; Novaes, H.T., 2004. Sobre o marco analíticoconceitual da tecnologia social. In: Tecnologia social: uma estratégia para o desenvolvimento. Fundação Banco do Brasil, Rio de Janeiro.
DIACONIA. s.d. 12 passos para construir um biodigestor. DIACONIA, Recife.

DIACONIA. 2016. Reaplicando o biodigestor a partir da mobilização social. DIACONIA, Recife.

DIACONIA. 2020. Entrevista de Ita Porto e Jucier Jorge concedida a: SOUZA, R. A. In: Souza, R.A. Uso do biodigestor como tecnologia social para produção de gás de cozinha. DIACONIA, Recife.

Empresa de Pesquisa Energética (EPE). 2019. Matriz energética e elétrica. EPE, Rio de Janeiro (Acessed April 9, 2020), at: http://www.epe.gov.br/pt/ abcdenergia/matriz-energetica-e-eletrica.

Fundação Banco do Brasil (FBB). 2018. Caminhos e perspectivas para a tecnologia social. Fundação Banco do Brasil, Instituto de Tecnologia Social, Brasília.

Gerhardt, T.E.; Silveira, D.T., 2009. Métodos de pesquisa. Editora da UFRGS, Porto Alegre. 
Gualdani, C.; Burgos, A., 2020. Mapeamento de fontes institucionais sobre tecnologias sociais na caatinga. Relatório técnico. Projeto Rural Sustentável Caatinga (PRS Caatinga). Fundação Brasileira para o Desenvolvimento Sustentável (FBDS), Rio de Janeiro.

Guimarães, P.R., 2008. Métodos quantitativos estatísticos. IESDE Brasil, Curitiba.

Herrero, J.M.; Donoso, M.P.; Mendoza, L.G.; Pedraza, G.X.; Jiménez, L.R.; Arias, J.V., 2016. Oportunidades para el desarrollo de un sector sostenible de biodigestores de pequeña y mediana escala en LAC. RedBioLac.

Intergovernmental Panel on Climate Change (IPCC). 2021. Climate change 2021. The Physical Science Basis. Summary for Policymakers. IPCC AR6 WGI. WMO, UNEP.

Jiménez, F.M.; Zambrano, D.A, 2018. Consumo de biogás en hogares rurales y sus implicaciones económicas y ambientales. Caso El Porvenir, Limón. Revista RedBioLAC, v. 2, 54-58.

Knopki, R.H., 2015. Segurança e prevenção de riscos na produção de biogás. Probiogás. Ministério das Cidades, Brasília, 35 pp.

Martins, S.; Schlindwein, S.; D’Agostini, L.; Bonatti, M.; Vasconcelos, A.; Hoffmann, A.; Fantini, A., 2010. Mudanças climáticas e vulnerabilidade na agricultura: desafios para desenvolvimento de estratégias de mitigação e adaptação. Brazilian Journal of Environmental Sciences (Online), (17), 17-27. (Accessed July, 2021) at: http://rbciamb.com.br/index.php/Publicacoes_ RBCIAMB/article/view/376.

Mattos, L.C., 2017. Um tempo entre secas: superação de calamidades sociais provocadas pela seca através das ações em defesa da convivência com o semiárido. Doctoral Thesis, CPDA, Universidade Federal Rural do Rio de Janeiro, Seropédica.

Mattos, L.C.; Júnior, M.F., 2011. Manual do biodigestor sertanejo. Projeto Dom Helder Câmara, Recife, 55 pp.
Meunier, I.M.J.; Silva, J.A.A.; Ferreira, R.L.C., 2001. Inventário florestal, programas de estudo. Departamento de Ciência Florestal, Universidade Federal Rural de Pernambuco, Recife.

Nicoloso, R.S.; Barros, E.C.; Wuaden, C.R.; Pigoso, A., 2019. Uso do digestato como fertilizante. In: Kunz A.; Steinmetz, R.L.R.; Amaral, A.C. (Eds.). Fundamentos da digestão anaeróbia, purificação do biogás, uso e tratamento do digestato. Sbera: Embrapa Suínos e Aves, Concórdia, 209 pp.

Nobre, C.A.; Salazar, L.F.; Oyama, M.; Cardoso, M.; Sampaio, G.; Lapola, D., 2007. Relatório $\mathrm{n}^{\circ}$ 6: mudanças climáticas e possíveis alterações nos biomas da América do Sul. CPTEC/INPE, IAE/CTA, São Paulo.

Quadros, D.G., 2009. Biodigestor na agricultura familiar do semiárido. EDUNEB, Salvador, $96 \mathrm{pp}$.

Rodrigues, I.; Barbieri, J.C., 2008. A emergência da tecnologia social: revisitando o movimento da tecnologia apropriada como estratégia de desenvolvimento sustentável. Revista de Administração Pública, v. 42, (6), 1069-1094. https://doi.org/10.1590/S0034-76122008000600003.

Silva, J.E.; Correia, L.A., 2020. Biodigestor sertanejo como alternativa para a conservação do semiarido potiguar. Holos, v. 6, e10125. https://doi. org/10.15628/holos.2020.10125.

Specht, M.J.S., 2012. Uso de lenha como combustível doméstico: padrões, impactos e perspectivas futuras para conservação da floresta atlântica ao norte do rio são Francisco. Master's Dissertation. Pós-Graduação em Biologia Vegetal, Centro de Ciências Biológicas, Universidade Federal de Pernambuco, Recife.

Ventura, A.C.; Garcia, L.F.; Andrade, J.C.S., 2012. Tecnologias sociais: as organizações não governamentais no enfrentamento das mudanças climáticas e na promoção de desenvolvimento humano. Cadernos EBAPE.BR, v. 10, (3), 605-629. https://doi.org/10.1590/S1679-39512012000300009. 